A.S. Madhu

Measurement Engineering Group Gas Turbine Research Establishment DRDO, Bengaluru 560093 India

D. Sethuram

Professor

Department of Mechanical Engineering PES University, Bengaluru 560085

India

V. Vijayalakshmi

Measurement Engineering Group Gas Turbine Research Establishment DRDO, Bengaluru 560093

India

P. G. Koppad

Department of Mechanical Engineering Nagarjuna College of Engineering and Technology Bengaluru 562164 India

\title{
Automatic Pressure Calibration System For Pressure Sensors
}

Pressure sensors are devices that sense the pressure and convert it into electrical signal whose magnitude depends upon the pressure applied. These sensors are employed in ground tests during engine development for aircrafts. The output (electrical signal) provided by these sensors form part of input to airworthiness checks of the aircraft. Hence, it needs to be re-verified or re-calibrated to evaluate its performance at specified or regular intervals of measurement and control. Towards this objective, sensor calibrations are performed using comparison method at Calibration Laboratory. Manual pressure calibration using hand pumps is a tiresome and time consuming process for metrologists. Metrologists find it very difficult to generate different steps and monitor pressure. The efforts will be further magnified in a laboratory environment where there will be a need to calibrate more numbers of pressure sensors on a regular basis. The situation further gets complicated with the different types and ranges of outputs from pressure sensors. The setup consists of a Precision Pressure Controller, Data Acquisition/switch unit and a Pressure manifold. An effort is made to exploit the capabilities of these instruments by automating the pressure calibration process by developing an automation software using NI LabVIEW.

Keywords: Calibration; Automation; Time factor; Accuracy; Transducer; Transmitter.

\section{INTRODUCTION}

Most of the structures which are light-weight are quite flexible but are prone to vibration. In this regard pressure sensors are used routinely to test the aero engines, wind turbine and other mechanical structures [1-6]. In addition to this the pressure sensors are also used to measure vibration levels. Calibration of pressure sensors is one of the most important aspect in the field of measurement and control. It is very much necessary to conduct a performance check of these sensors at regular intervals. In calibration laboratory, the calibration of pressuresensors is carried out using comparison method $[7,8]$. The setup consists of a Pressure Controller/Calibrator, Data Acquisition/Switch unit, pressure distribution manifold and a computer that controls all these instruments. The output of the pressure sensors under calibration (will be called DUT here on wards) is compared with the standard pressure controller/calibrator and the results are recorded. Initially the pressure calibration was done manually. Depending on the range of the pressure sensor, five set points within the Range for calibration is decided and set using the controller front panel menus one after the other and the output of the sensor (also called a Device Under Test, DUT) was measured using Data logger individually [9]. The process was time consuming and

Received: August 2018, Accepted: November 2018

Correspondence to: A S Madhu

Measurement Engineering Group, Gas Turbine

Research Establishment, DRDO, Bengaluru, India

E-mail:madhuas@gtre.drdo.in

doi: 10.5937/fmet1901111M

(C) Faculty of Mechanical Engineering, Belgrade. All rights reserved prone to manual errors.

An automation of pressure calibration using pressure controller/calibrator and data acquisition/switch unitwas planned using NI LabVIEW software. Software is developed to interface pressure controller/calibrator and data acquisition/switch unit using serial port. The software is controlling thecontroller with set point generation and measure the output of the DUT at the data acquisition/switch unit. The features of the software are automatic set point generation, overpressure protection and data logging.

\section{EXPERIMENTAL SETUP}

An illustration and actual setupof pressure calibration system as shown in Figure 1 and 2 respectively consists of a personal computer interfaced with pressure controller/calibrator, PPC4 and a data acquisition/switch unit, 34970A. The instruments are controlled by a personal computer. They are connected to computer using serial interface, RS232. Software is developed using Lab VIEW. The DUTsare connected using a multi-point feeding system (pressure distribution manifold) to the pressure controller. This enables many DUTs to be connected at a time for simultaneous calibration.

\subsection{PPC4, Pressure Controller/Calibrator}

The pressure controller/calibrator is a stand-alone, pressure controller intended to precisely set and control gas pressure into a closed volume as is commonly needed for the calibration and testing of pressure measuring instruments and is shown in Figure 3. 
PPC4 uses Quartz Reference Pressure Transducers (Q-RPTs). A reference barometer is also included. The on-board barometer is used only to measure changes in atmospheric pressure to provide dynamic compensation of the Q-RPTs atmospheric pressure offset when using an Axxx (absolute)(Q-RPT to make gauge pressure measurements. The accuracy of this controller is $\pm 0.012 \%$ of reading.

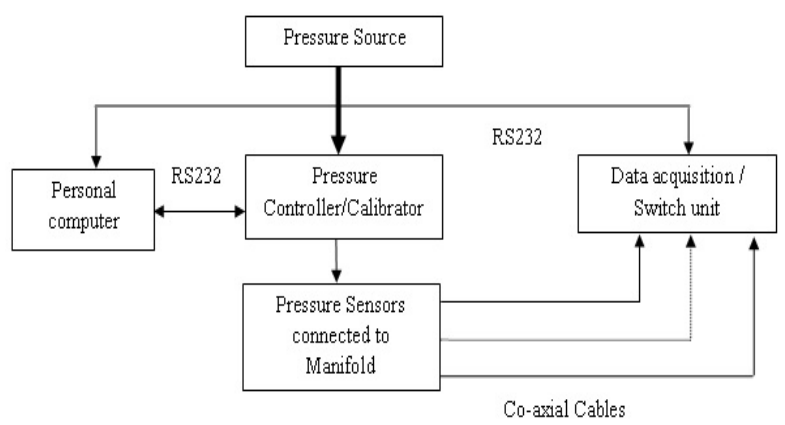

Figure 1. Illustration of pressure calibration system

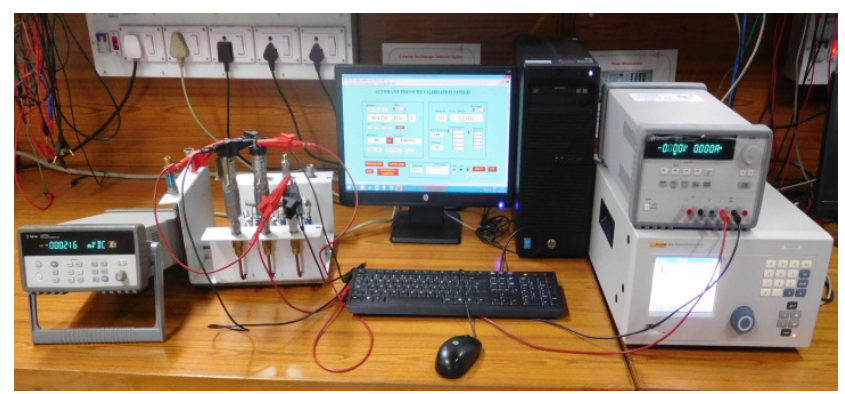

Figure 2. Actual set-up of pressure calibration system

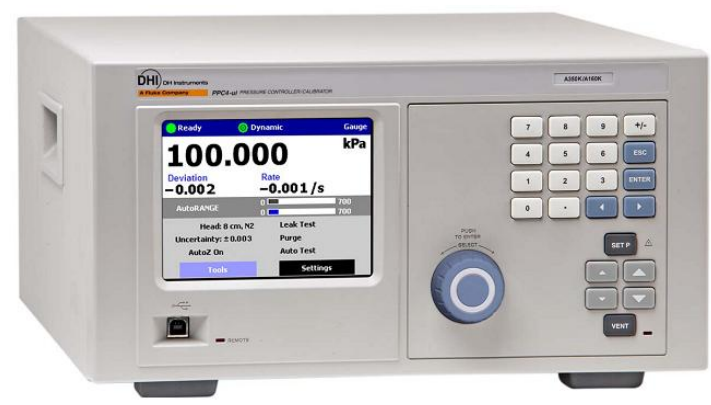

Figure 3. PPC4 pressure controller/calibrator

\subsection{Data Acquisition / SwitchUnit}

The data acquisition/switch unit is a $6 \frac{1}{2}$ digit Multimeter which offers good stability and noise rejection designed to measure thermocouples, resistance temperature detectors, $\mathrm{AC} / \mathrm{DC}$ voltage, $\mathrm{AC} / \mathrm{DC}$ current, resistance and frequency which is shown in Figure 4.

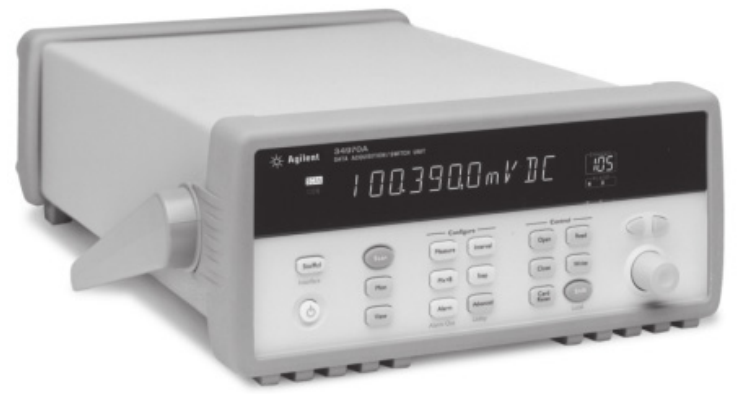

Figure 4. Data acquisition/switch unit
The instrument has multiplexer cards (maximum of 3 upto 20 numbers) where DC measurements per multiplexer card can be made. ' $Z$ ' electrical signals to be measured are connected to these multiplexer cards and are addressed by the channel numbers.In this program this instrument is used to measure DC voltage, DC current \& frequency with an accuracy of $\pm 40 \mathrm{ppm}$ in DC voltage.

\subsection{Pressure Distribution Manifold}

The pressure distribution manifold pneumatic is a compact and easy to use system for connecting maximum of 6 sensors simultaneously which is required to be calibrated. This manifold has one input port where pressure standard is connected. It also has a port to connect indicating device like pressure gauge. The manifold (as shown in Figure 5) has built in valves to isolate the port which are to be blanked during use. The pressure distribution manifold pneumatic has a working range between Vacuum and 3.5 MPa.

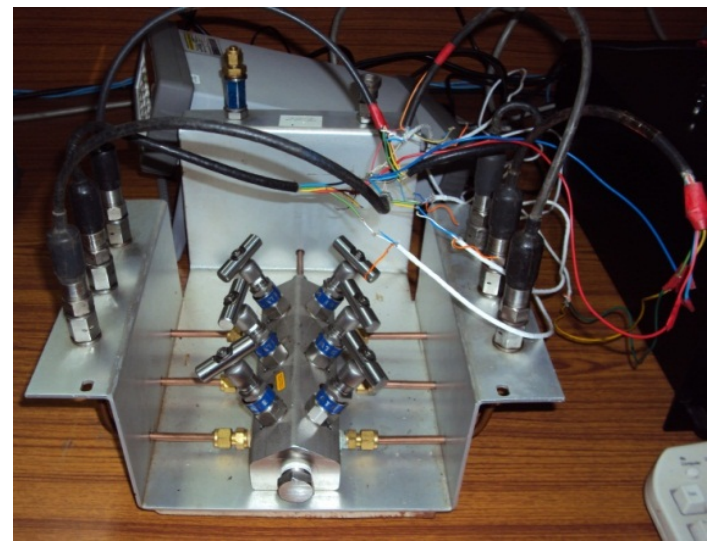

Figure 5. Pressure distribution manifold

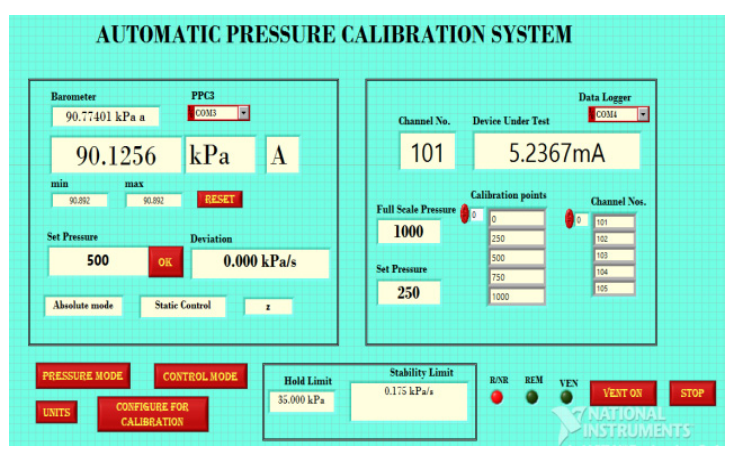

Figure 6. Program front panel

\subsection{Front panel}

The front panel of the program is given in Figure 6. The front panel is the main menu which interacts with the user. The user has to initially configure PPC4 for pressure units, pressure mode and control mode from the front panel buttons. The user has to configure the data acquisition/switch unit also for voltage/current /frequency measurement, as per the sensor output. The channel numbers where the output of the sensors are connected in the multiplexer card of data acquisition /switch unit also has to be entered along with the details of the DUT, i.e., manufactured by, model number, Serial number, range and accuracy of sensors. 
Once the configuration is completed the operator can initiate the calibration process. The software will step by step perform calibration and give the results and generate report automatically which is saved in an excel format. After calibration the program vents the system automatically and puts it into the safe mode. Front panel of the program is given in Figure 6.

\section{RESULTS AND DISCUSSION}

The calibration result generated from the software for one pressure transmitter (Manufactured by: Druck, Model No.: PTX511)is shown in Table 1. The calibration graph for the pressure transmitter is shown in Figure 7. The calibration result generated from the software for one pressure transducer (Manufactured by: Druck, Model No.: PTX511)done is shown in Table 2. Taking the calibration result from the Table 2, the calibration graph is plotted for the pressure transducer and is shown in Figure 8.

\section{Table 1.Calibration result of pressure transmitter}

\begin{tabular}{|c|c|c|c|}
\hline \multicolumn{4}{|c|}{ Type: Pressure transmitter } \\
\hline \multicolumn{4}{|c|}{ Manufactured by: Druck } \\
\hline \multicolumn{4}{|c|}{ Model No.: PTX511 } \\
\hline \multicolumn{4}{|c|}{ Serial number.: 1138817} \\
\hline $\begin{array}{c}\text { Standard } \\
\text { Pressure } \\
\text { (in kPa) }\end{array}$ & $\begin{array}{l}\text { DUT Output } \\
\quad \text { (in } \mathrm{mA} \text { ) }\end{array}$ & \multicolumn{2}{|c|}{$\begin{array}{l}\text { Non-Linearity } \\
\text { (in } \% \text { of FS) }\end{array}$} \\
\hline 0 & 4.028 & 0.014 & Within \\
\hline 172.369 & 8.023 & -0.007 & Within \\
\hline 344.738 & 12.016 & -0.015 & Within \\
\hline 517.107 & 16.006 & -0.004 & Within \\
\hline 689.476 & 19.995 & 0.012 & Within \\
\hline
\end{tabular}

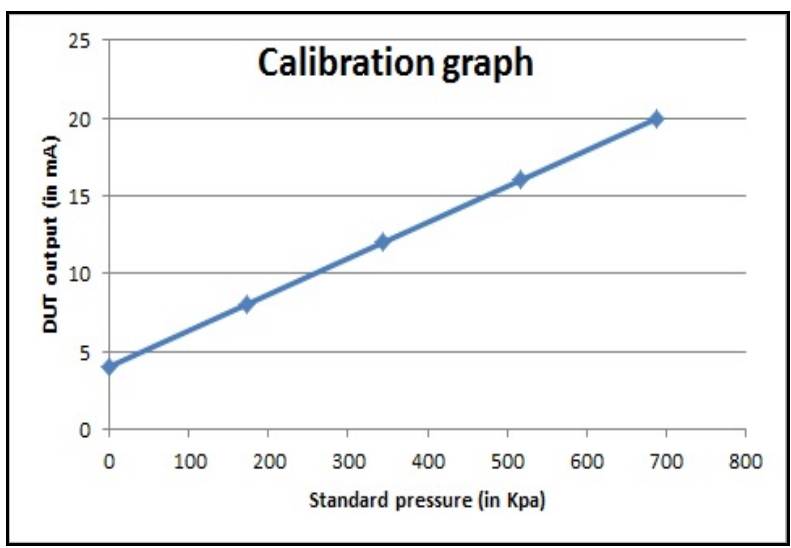

Figure 7. Calibration graph for pressure transmitter

Table 2. Calibration result of pressure transmitter

\begin{tabular}{|c|c|c|c|}
\hline \multicolumn{4}{|l|}{ Type: Pressure Transmitter } \\
\hline \multicolumn{4}{|l|}{ Manufactured by: Druck } \\
\hline \multicolumn{4}{|l|}{ Model No.: PTX511 } \\
\hline \multicolumn{4}{|l|}{ Serial number: 1134654 } \\
\hline $\begin{array}{c}\text { Standard } \\
\text { Pressure } \\
\text { (in kPa) }\end{array}$ & $\begin{array}{c}\text { DUT } \\
\text { Output } \\
\text { (in mA) }\end{array}$ & \multicolumn{2}{|c|}{$\begin{array}{c}\text { Non-Linearity } \\
\text { (in \% of FS) }\end{array}$} \\
\hline 0 & 3.985 & 0.265 & Within \\
\hline 1723.69 & 8 & -0.102 & Within \\
\hline 3447.38 & 11.98 & -0.249 & Within \\
\hline 5171.07 & 15.94 & -0.269 & Within \\
\hline 6894.76 & 19.798 & $0.355^{*}$ & Out of \\
\hline
\end{tabular}

(* Indicates out of tolerance data.)

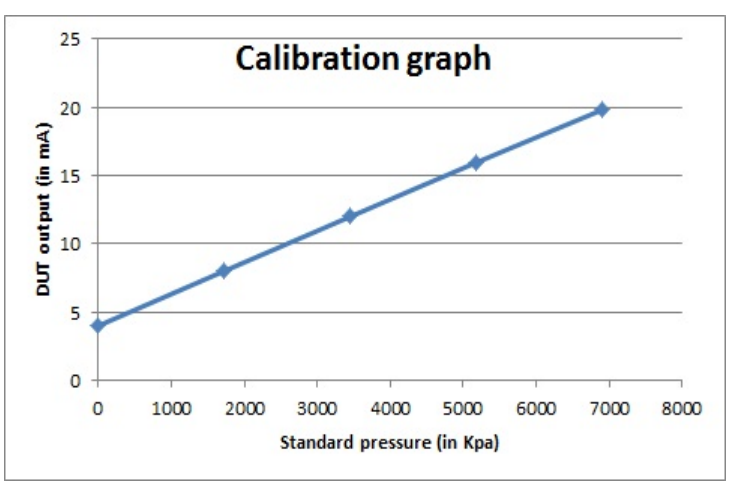

Figure 8.Calibration graph for pressure transducer.

Table 3. Calibration result of pressure transducer

\begin{tabular}{|l|c|c|c|}
\hline \multicolumn{3}{|l|}{ Type: Pressure transducer } \\
\hline \multicolumn{4}{|l|}{ Manufactured by: Druck } \\
\hline \multicolumn{4}{|l|}{ Model Number: PTX511 } \\
\hline Serial number: 4098328 \\
\hline $\begin{array}{c}\text { Standard } \\
\text { Pressure } \\
\text { (in Kpa) }\end{array}$ & $\begin{array}{c}\text { DUT Output } \\
\text { (in V) }\end{array}$ & \multicolumn{2}{|c|}{$\begin{array}{c}\text { Non-Linearity } \\
\text { (in \% of FS) }\end{array}$} \\
\hline 90.98325 & 0.4433 & 0.03 & Within \\
\hline 517.107 & 2.501 & 0.01 & Within \\
\hline 1034.214 & 4.999 & -0.01 & Within \\
\hline 1551.321 & 7.500 & 0 & Within \\
\hline 2068.428 & 10.003 & 0.03 & Within \\
\hline
\end{tabular}

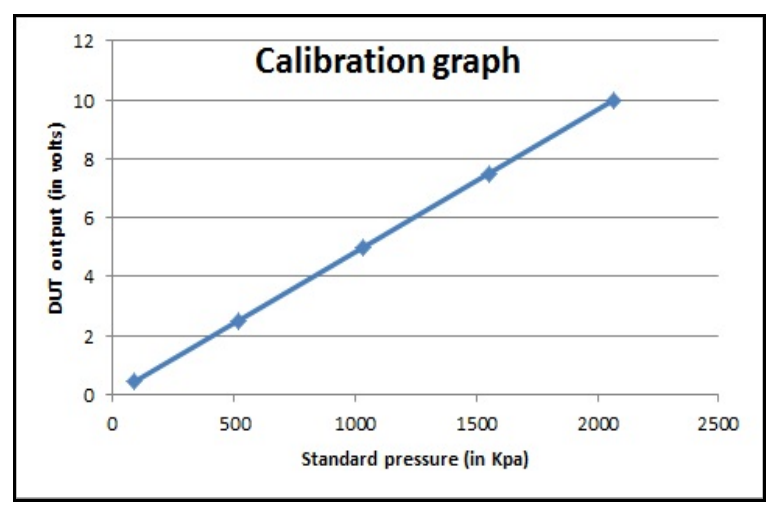

Figure 9. Calibration graph for pressure transducer

The accuracy is calculated based on the following formulae:

Conversion of pressure to voltage in pressure transducers with voltage output is given by following expression [10],

$$
\text { Output voltage }=\frac{\text { Full scale output voltage }}{\text { Full scale pressure }} \times I P
$$

Conversion of pressure to Current in pressure transmitter with current output $(4-20 \mathrm{~mA})$ is given by following expression [10],

$$
\text { Output current }=\frac{(16 \times I P)}{\text { Full scale pressure }}+4
$$

For $\%$ of reading we have [10],

$\% \mathbf{f} R d g=\frac{(\text { Standard reading }- \text { DUT reading })}{\text { Standard reading }} \times 100$

For $\%$ of FS we have [10], 
$\% \mathbf{f} F S=\frac{(\text { Standard reading }- \text { DUT reading })}{\text { Full scale reading }} \times 100$

where IP is input pressure.

Table 4. Calibration result of pressure transducer

\begin{tabular}{|c|c|c|c|}
\hline \multicolumn{3}{|l|}{ Type: Pressure transducer } \\
\hline \multicolumn{4}{|l|}{ Manufactured by: Druck } \\
\hline \multicolumn{4}{|l|}{ Model Number: PTX511 } \\
\hline Serial number: 4105626 \\
\hline $\begin{array}{c}\text { Standard } \\
\text { Pressure } \\
\text { (in Kpa) }\end{array}$ & $\begin{array}{c}\text { DUT Output } \\
\text { (in V) }\end{array}$ & \multicolumn{2}{|c|}{$\begin{array}{c}\text { Non-Linearity } \\
\text { (in \% of FS) }\end{array}$} \\
\hline 90.98325 & 0.4419 & 0.02 & Within \\
\hline 517.107 & 2.500 & 0 & Within \\
\hline 1034.214 & 4.998 & -0.02 & Within \\
\hline 1551.321 & 7.499 & -0.01 & Within \\
\hline 2068.428 & 9.998 & -0.02 & Within \\
\hline
\end{tabular}

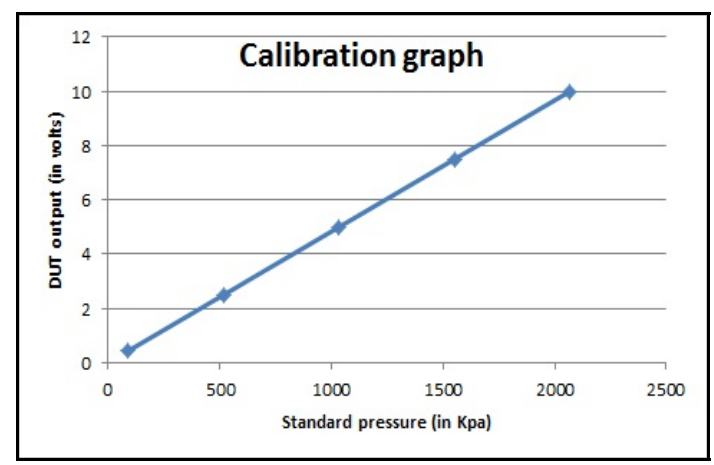

Figure 10. Calibration graph for pressure transducer

Table 5. Calibration result of pressure transmitter

\begin{tabular}{|c|c|c|c|}
\hline \multicolumn{4}{|c|}{ Type: Pressure transmitter } \\
\hline \multicolumn{4}{|c|}{ Manufactured by: Keller } \\
\hline \multicolumn{4}{|c|}{ Model Number: PAA33X } \\
\hline \multicolumn{4}{|c|}{ Serial number: 430716} \\
\hline $\begin{array}{l}\text { Standard } \\
\text { Pressure } \\
\text { (in Kpa) }\end{array}$ & $\begin{array}{l}\text { DUT Output } \\
\quad \text { (in } \mathrm{mA} \text { ) }\end{array}$ & \multicolumn{2}{|c|}{$\begin{array}{l}\text { Non-Linearity } \\
\text { (in } \% \text { of FS) }\end{array}$} \\
\hline 20 & 7.236 & -0.18 & Within \\
\hline 40 & 10.437 & -0.18 & Within \\
\hline 60 & 13.636 & -0.18 & Within \\
\hline 80 & 16.854 & $-0.27 *$ & Out of \\
\hline 100 & 20.041 & -0.20 & Within \\
\hline
\end{tabular}

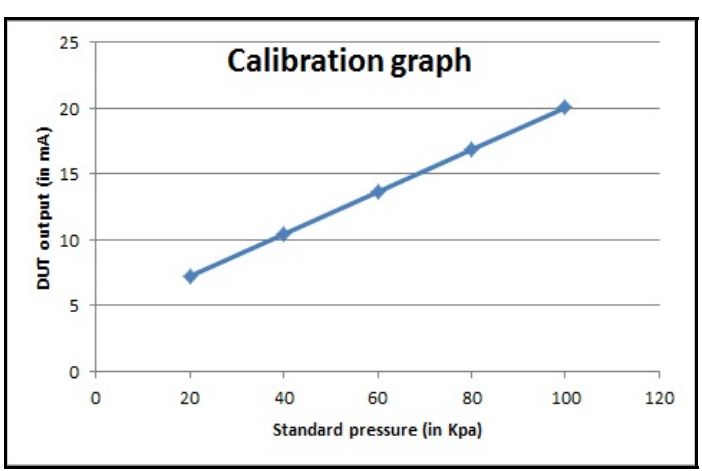

Figure 11. Calibration graph for pressure transmitter

The calibration of one pressure sensor and one pressure transmitter is presented here. The result is automatically generated and provided in the form of report by the software referenceTables $1-6$. The accuracy deviation is listed in the right most column indicating the accuracy status whether the sensor is within or out of accuracy. The calibration graph gives a visual inspection of calibration deviation immediately. The results are obtained quickly in a tabular and graphical format [11].

Table 6. Calibration result of pressure transmitter

\begin{tabular}{|c|c|c|c|}
\hline \multicolumn{4}{|c|}{ Type: Pressure transmitter } \\
\hline \multicolumn{4}{|c|}{ Manufactured by: Keller } \\
\hline \multicolumn{4}{|c|}{ Model Number: PAA33X } \\
\hline \multicolumn{4}{|c|}{ Serial number: 435893} \\
\hline $\begin{array}{l}\text { Standard } \\
\text { Pressure } \\
\text { (in Kpa) }\end{array}$ & $\begin{array}{l}\text { DUT Output } \\
\text { (in } \mathrm{mA} \text { ) }\end{array}$ & \multicolumn{2}{|c|}{$\begin{array}{l}\text { Non-Linearity } \\
\text { (in } \% \text { of FS) }\end{array}$} \\
\hline 20 & 7.234 & -0.17 & Within \\
\hline 40 & 10.437 & -0.18 & Within \\
\hline 60 & 13.639 & -0.19 & Within \\
\hline 80 & 16.841 & -0.20 & Within \\
\hline 90.664 & 18.55 & $-0.22 *$ & Out of \\
\hline
\end{tabular}

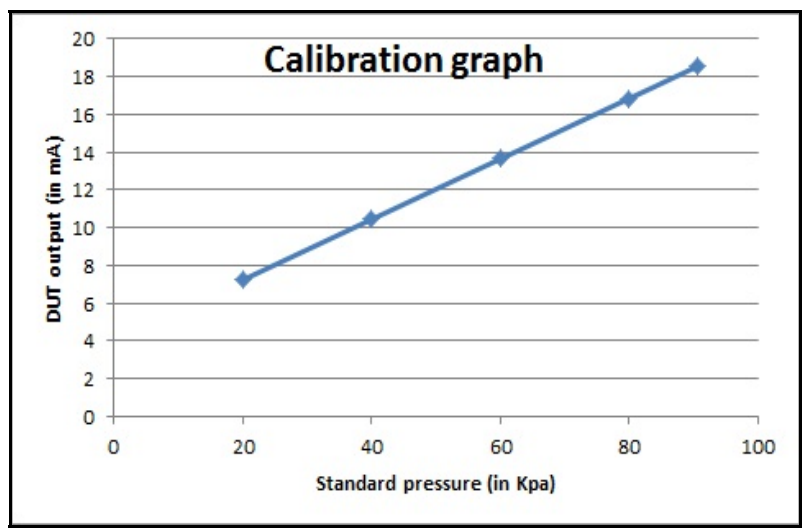

Figure 12. Calibration graph for pressure transmitter

The proposed facility is a new development in the field of calibration. Such a setup is not available commercially.The proposed automation has reduced human errors and speeded the calibration activity. The errors of operation are also reduced. It is possible to calibrate many sensors at the same time. It also provides at most safety to the user and the equipment. This has reduced the calibration time from 18 hours to 1 hour.

\section{CONCLUSIONS}

The automation of sensor calibration carried out using PPC4 and software is helpful in calibration of 60 sensors at a time. This system has made the calibration work faster and simpler by making the calibration process fully automatic. This system is capable of generating the report of observations along with the plot of pressure verses electrical output automatically. The measurement system capability is fully utilized by using the software program. Apart from enhancing productivity, this calibration system has brought in repeatability and consistency by making the calibration process operator independent. Hence, routine calibration work load of pressure sensors can be achieved more effectively.

\section{ACKNOWLEDGMENTS}

This development was done in Gas Turbine Research Establishment to automate pressure calibration process. Members of calibration laboratory were of valuable assistance on several phases of development. 


\section{REFERENCES}

[1] Jovanova, J., Gavriloski, V., Djidrov, M., Tasevski, G. Model based vibration control of smart flexible structure using piezoelectric transducers, FME Transactions, Vol. 43, pp. 70-75, 2015.

[2] Ilić, Z. et al.: Impact of changing quality of air/fuel mixture during flight of a piston engine aircraft with respect to vibration low frequency spectrum, FME Transactions, Vol. 41, No 1, pp. 25-32, 2013.

[3] Ilić, Z. et al.: Potential connections of cockpit floor - seat on passive vibration reduction at a piston propelled airplane, Technical Gazette, Vol.21 No.3, pp. 471-478, 2014

[4] Ilić, Z. et al.: The efficiency of passive vibration damping on the pilot seat of piston propeller aircraft, Measurement, Vol. 95, pp. 21-32, January 2017.

[5] Matijević, DV., Popović, VM.: Overview of Modern Contributions in Vehicle Noise and Vibration Refinement with Special Emphasis on Diagnostics, FME Transactions, Vol. 45 No 3, pp. 448-458, 2017.

[6] Djidrov, M., Gavriloski, V., Jovanova, J.: Vibration analysis of cantilever beam for damage detection, FME Transactions, Vol. 42, pp. 311-316, 2014.

[7] Doebelin, E.O., Gross, A. W.: Measurement Systems Application And Design, Tata McGraw Hill, New Delhi, 2002.

[8] ISO 17025 - General requirements for the competence of testing and Calibration laboratories.

[9] User manual for PPC4 \& Data acquisition / switch unit.

[10] Irwin, J.D. and Nelms, R.M.: Basic Engineering Circuit Analysis, John Wiley and Sons, New Delhi, 2005.
[11] Gustavsson, I., Zackrisson, J., Akesson, H., Hakansson, L., Claesson, I.,Lago T.: Remote operation and control of traditional laboratory equipment in: Fourth International Conference on Systems and Networks Communications, 2009.

\section{СИСТЕМ ЗА АУТОМАТСКУ КАЛИБРАЦИЈУ ПРИТИСКА КОД СЕНЗОРА ПРИТИСКА}

\section{А.С. Мадху, Д. Сетхурам, В. Вијајалакшми, П.Г. Копад}

Сензори притиска су уређаји који мере притисак и конвертују га у електрични сигнал чија магнитуда зависи од примењеног притиска. Сензори се користе код теренских испитивања приликом изградње мотора за летелице. Излаз (електрични сигнал) који стварају сензори формира део улаза за проверу пловидбености летелице. Отуда је потребно извршити реверификацију и рекалибрацију у циљу евалуације перформанси у одређеним и правилним интервалима мерења и управљања. У ту сврху врши се калибрација сензора помоћу методе поређења у лабораторији за калибрацију. Код мануелне калибрације користе се ручне пумпе што је напоран и дуготрајан процес за метрологе. Метролози сматрају да је тешко одредити кораке у процесу и пратити притисак. У лабораторијским условима ће се извршити већи број калибрација сензора притиска. Ситуација се усложњава због коришћења различитих типова сензора који дају различите резултате. Експериментална инсталација се састоји од прецизног контролера за притисак, уређаја за аквизицију података и колектора притиска. Истражене су могућности аутоматизације ових инструмената у процесу калибрације притиска развијањем софтвера Ni LabVIEW. 